\title{
Аналіз ускладнень гострого гнійного медіастиніту
}

\author{
І. М. Шевчук, С. С. Сніжко \\ Івано-Франківський національний медичний університет

\section{Analysis of complications of an acute purulent mediastinitis}

\author{
I. M. Shevchuk, S. S. Snizhko \\ Ivano-Frankivsk National Medical University
}

\begin{abstract}
Peфepaт
Вступ. Гострий гнійний медіастиніт (ГГМ) залишається однією із найбільш тяжких форм загальної хірургічної інфекції. Розвиток ускладнень $є$ одним із вирішальних факторів у перебігу захворювання.

Матеріали і методи. Впродовж 2000 - 2017 рр. у торакальному відділенні Івано-Франківської обласної клінічної лікарні проходили лікування 65 хворих із ГГМ.

Результати. Ексудативний плеврит та емпієму плеври виявлено у 76,9\%, гнійний бронхіт - у 80\%, пневмонію - у 70,7\%, ендо- і міокардит - у 59,2\%, гостре ураження нирок - у 24,6\%, сепсис - у $100 \%$ хворих із тотальним і заднім медіастинітом.

Висновки. Попередження розвитку ускладнень та їх лікування $є$ важливою умовою успішного лікування хворих із ГГМ.

ключові слова: гострий гнійний медіастиніт; ускладнення медіастиніту.

Abstract

Introduction. An acute purulent mediastinitis (APM) persists as one of most severe forms of common surgical infections. Development of complications constitutes one of principal factors in the disease course.

Materials and methods. Through 2000 - 2017 yrs in Thoracic Department of Ivano-Frankivsk Regional Clinical Hospital 65 patients, suffering an APM, were treated.

Results. Exudative pleuritis and pleural empyema was revealed in $76,9 \%$, purulent bronchitis - in $80 \%$, pneumonia - in $70,7 \%$, endo- and myocarditis - in 59,2\%, an acute renal affection - in 24,6\%, sepsis - in 100\% patients, suffering total and posterior mediastinitis.

Conclusion. Prevention of the complications occurrence and their treatment constitutes a principal prerequisite of successful treatment in patients, suffering APM.

Keywords: acute purulent mediastinitis; complications of mediastinitis.
\end{abstract}

Гострий гнійний медіастиніт (ГГМ) вважають однією із найбільш тяжких форм загальної хірургічної інфекції, що характеризується агресивним клінічним перебігом, швидким розвитком синдрому системної запальної відповіді та тяжкого сепсису $з$ поліорганною недостатністю $[1,2]$. Оскільки в грудній порожнині розміщені життево важливі органи, гнійний процес часто розповсюджується контактним шляхом і спричиняє розвиток тяжких ускладнень, які є прямою загрозою життю хворих [3]. Таким чином, одним із вирішальних факторів у перебігу та прогнозі ГГм є наявність та розвиток його ускладнень [4].

Мета дослідження: визначення найбільш типових ускладнень ГГМ, аналіз причин ї розвитку та летальності в залежності від характеру і виду ускладнення.

\section{Матеріали і методи дослідження}

За період з 2000 по 2017 р. у торакальному відділенні Івано-Франківської обласної клінічної лікарні перебували 65 хворих із ГГМ, серед них 43 (66,1\%) чоловіки і 22 (33,9\%) жінки віком від 21 до 76 років, середній вік становив $(36,3 \pm 3,9)$ року.

Передньо-верхній ГГМ діагностований у 22 (33,8\%), верхній - у 16 (24,6\%), задній - у 8 (12,3\%), тотальний - у 19 (29,2\%) хворих. Первинний ГГМ був у 21 (32,3\%), вторинний - у 44 (67,7\%) хворих. У 29 (44,6\%) хворих виконана правобічна бокова торакотомія, у 25 (38,5\%) - лівобічна, у 2 (3\%) - двобічна, у 4 (6,1\%) - бокова торакото- мія 3 одночасною відеоторакоскопією з протилежного боку, у 5 (7,7\%) - шийна цервікотомія з відеоторакоскопією. Післяопераційна летальність становила 26,1\% (померли 17 із 65 хворих). Середній термін перебування у стаціонарі - $(28 \pm 4)$ доби.

У хворих з ГГМ проаналізовані результати лабораторних досліджень, рентгенографії у двох проекціях, комп'ютерної томографії, ультразвукового обстеження органів грудної порожнини, електрокардіографії та ехокардіоскопії, фібробронхоскопії, ендоскопічного обстеження верхніх відділів травного каналу. Враховували також зміни тканин і органів середостіння і шиї під час проведення операційних втручань та результати патологоанатомічного дослідження щодо особливостей локалізації та розповсюдження гнійного процесу на шиї і в середостінні.

\section{Результати}

Найчастіше при ГГМ розвивається емпієма плеври [5]. Гостра емпієма плеври погіршує перебіг захворювання, зумовлюючи наростання явищ гнійної інтоксикації [2]. Ексудативний плеврит та емпієма плеври часто бувають двобічними, що більш притаманно задньому ГГм. Частота виникнення ексудативного плевриту та емпієми плеври залежить від виду ГГМ (табл. 1).

Появу ексудату в плевральній порожнині діагностовано у 100\% хворих при задньому і тотальному ГГМ. Об'єм ексудату залежав від виду ГГм та тривалості пере- 


\begin{tabular}{|c|c|c|c|c|c|c|c|c|c|c|}
\hline \multirow{3}{*}{ Характер ураження } & \multicolumn{10}{|c|}{ Вид ГгМ } \\
\hline & \multicolumn{2}{|c|}{ передньо-верхній } & \multicolumn{2}{|c|}{ верхній } & \multicolumn{2}{|c|}{ задній } & \multicolumn{2}{|c|}{ тотальний } & \multicolumn{2}{|c|}{ Всього } \\
\hline & абс. & $\%$ & абс. & $\%$ & абс. & $\%$ & абс. & $\%$ & абс. & $\%$ \\
\hline \multicolumn{11}{|l|}{ Плеврит } \\
\hline однобічний & 9 & 40,9 & 2 & 12,5 & - & - & 1 & 5,26 & 12 & 18,5 \\
\hline двобічний & 3 & 13,6 & 3 & 13,6 & - & - & 3 & 15,8 & 9 & 13,8 \\
\hline \multicolumn{11}{|l|}{ Емпієма плеври } \\
\hline однобічна & 1 & 4,5 & 2 & 12,5 & 7 & 87,5 & 4 & 21,1 & 14 & 21,5 \\
\hline двобічна & 1 & 4,5 & 2 & 12,5 & 1 & 12,5 & 11 & 57,9 & 15 & 23,1 \\
\hline Разом ... & 14 & 63,6 & 9 & 56,2 & 8 & 100 & 19 & 100 & 50 & 76,9 \\
\hline
\end{tabular}

\begin{tabular}{|c|c|c|c|c|c|c|c|c|c|c|}
\hline \multicolumn{11}{|c|}{ Ураження бронхо-легеневої системи у хворих із ГГМ } \\
\hline \multirow{3}{*}{ Характер ураження } & \multicolumn{10}{|c|}{ Вид ГГМ } \\
\hline & \multicolumn{2}{|c|}{ передньо-верхній } & \multicolumn{2}{|c|}{ верхній } & \multicolumn{2}{|c|}{ задній } & \multicolumn{2}{|c|}{ тотальний } & \multicolumn{2}{|c|}{ Всього } \\
\hline & абс. & $\%$ & абс. & $\%$ & абс. & $\%$ & абс. & $\%$ & абс. & $\%$ \\
\hline Гнійний бронхіт & 17 & 77,3 & 12 & 75 & 6 & 75 & 17 & 89,4 & 52 & 80 \\
\hline Пневмонія & 14 & 63,6 & 11 & 68,7 & 5 & 62,5 & 16 & 84,2 & 46 & 70,7 \\
\hline Абсцес легень & - & - & - & - & 1 & 12,5 & 3 & 15,8 & 4 & 6,1 \\
\hline $\begin{array}{l}\text { Гострий респіраторний } \\
\text { дистрес-синдром }\end{array}$ & 1 & 4,5 & 1 & 6,2 & 2 & 25 & 12 & 63,1 & 13 & 20 \\
\hline
\end{tabular}

бігу гнійного процесу - у середньому (630 \pm 90$)$ мл. При задньому ГГМ, причиною якого був спонтанний розрив стравоходу, об'єм гнійного ексудату в плевральній порожнині був більшим - від 550 до 2700 мл. При передньо-верхньому ГГМ здебільшого відмічали накопичення плеврального ексудату в об'ємі від 20 до 560 мл. Розвиток емпієми плеври погіршував перебіг ГГм за рахунок компресії легень із наростанням проявів дихальної недостатності та інтоксикації внаслідок збільшення площі резорбції гнійного ексудату.

Розповсюдження гнійно-запального процесу навколо трахеї та бронхів призводить до їх контактного інфікування та розвитку тяжкого гнійного бронхіту і пневмонії. Пневмонія у хворих із ГГМ розвивається також через обмеження дихальної екскурсії легень, зумовлене тривалим перебуванням хворого у вимушеному положенні, вторинним запаленням міжреберних м'язів і діафрагми; порушення відтоку крові по легеневих венах з розвитком застійних змін у легеневій паренхімі. Внаслідок вторинного інфекційного ураження паренхіми легень та обструкції бронхів на фоні гнійної інтоксикації можливий розвиток абсцесу легень, чому сприяє аспірація гнійних мас при гнійному бронхіті. В результаті ураження легень при сепсисі часто виникає гострий респіраторний дистрес-синдром, що може прямо загрожувати життю хворого [5]. Частота і характер ураження бронхо-легеневої системи у хворих із ГГМ наведені в табл. 2 .

Перебіг захворювання був значно тяжчим при тотальному ГГМ. Слід також відзначити, що у 54 (83\%) хворих із ГГм діагностовано по декілька захворювань бронхолегеневої системи, зокрема, гнійний бронхіт та пневмонію - у 43 (79,6\%), гнійний бронхіт та абсцес легень - у 21 (38,9\%), гострий респіраторний дистрес-синдром та пневмонію - у 12 (22,2\%) хворих.

Одним із загрозливих ускладнень ГГМ є гострий гнійний перикардит, розвиток якого можливий при пору- шенні відтоку ексудату з порожнини перикарда внаслідок компресії вен запальним інфільтратом середостіння та контактного інфікування. Це призводить до поширення запальних змін на серцевий м'яз із розвитком інфекційно-токсичного міокардиту і серцевої недостатності. Гострий гнійний перикардит діагностували переважно при задньому та тотальному ГГМ: у 6 (75\%) із 8 та у $16(84,2 \%)$ iз 19 хворих відповідно. На жаль, гострий гнійний перикардит не можна розглядати як ранню діагностичну ознаку захворювання. Його розвиток супроводжується тяжкими серцево-судинними порушеннями і значно ускладнює лікування хворого.

Ураження серцево-судинної системи мали всі хворі з ГГМ. Часто відзначали тахікардію - до 120 за 1 хв, яка могла раптово змінитися на брадикардію - до 52 за 1 хв. Частота розвитку ендо- і міокардиту при вторинному ГГМ може сягати 56\% [6]. За нашими даними, при передньо-верхньому та верхньому ГГМ ендо- і міокардит діагностовано у $3(7,9 \%)$ із 38, при задньому і тотальному у 16 (59,2\%) із 27 хворих. Це дає підставу стверджувати, що при передньо-верхньому та верхньому ГГМ ураження міокарда має переважно інфекційно-токсичний механізм, при задньому і тотальному - контактний. За даними електрокардіографії дифузні зміни міокарда виявлені у 100\% хворих із ГГМ, із них помірні зміни міокарда - у 41 (63\%), значні - у 24 (37\%). Порушення процесів реполяризації міокарда, синусову тахікардію, поодинокі передсердні та шлуночкові екстрасистоли діагностовано у $49(75,4 \%)$ хворих.

Частим ускладненням ГГм є розвиток дисфункції печінки. За рахунок вираженої гнійної інтоксикації страждає синтез альбуміну. Внаслідок посиленого катаболізму рівень альбуміну знижується, зростає рівень глобулінів 3 тенденцією до гіпо- і диспротеїнемії. Середній вміст загального білка в крові був знижений у 58 (89,2\%) хворих і становив у середньому $(57,3 \pm 5,1)$ г/л. Гепатоцелюлярне 


\begin{tabular}{|c|c|c|c|c|c|c|c|c|c|c|}
\hline \multirow{3}{*}{ Форма сепсису } & \multicolumn{10}{|c|}{ Вид ГгМ } \\
\hline & \multicolumn{2}{|c|}{ передньо-верхній } & \multicolumn{2}{|c|}{ верхній } & \multicolumn{2}{|c|}{ задній } & \multicolumn{2}{|c|}{ тотальний } & \multicolumn{2}{|c|}{ Всього } \\
\hline & абс. & $\%$ & абс. & $\%$ & абс. & $\%$ & абс. & $\%$ & абс. & $\%$ \\
\hline Сепсис & 19 & 86,3 & 15 & 93,7 & 5 & 52,5 & 6 & 42,1 & 45 & 69,2 \\
\hline Септичний шок & - & - & - & - & 1 & 12,5 & 5 & 21,1 & 6 & 9,2 \\
\hline $\mathrm{C \Pi OH}$ & - & - & 1 & 6,3 & 2 & 25,0 & 8 & 36,8 & 11 & 16,9 \\
\hline Разом... & 19 & 86,3 & 16 & 100 & 8 & 100 & 19 & 100 & 62 & 95,3 \\
\hline
\end{tabular}

ураження діагностували за зростанням активності ферментів цитоплазматичних мембран - аспартатамінотрансферази (АсАТ), аланінамінотрансферази (АлАТ) та лужної фосфатази. Рівні АсАТ та АлАТ перевищували верхню межу норми у 42 (64,6\%) хворих і становили у середньому 0,78 та 0,84 мкмоль/л відповідно. Ураження печінки при ГГМ спричиняє також гіпербілірубінемію. Збільшення рівня загального білірубіну в сироватці крові виявлено у 40 (61,5\%) хворих, у середньому цей показник становив $(27,4 \pm 3,2)$ мкмоль/л. Під час ультразвукового дослідження (УЗД) патологічні зміни паренхіми печінки верифікували у разі збільшення ії розмірів, виникнення ділянок ущільнення та неоднорідністі ЕXOструктури, що виявлено у 41 (63,1\%) хворого. За даними лабораторних аналізів та УЗД печінкову дисфункцію встановили у 61 (93,8\%) хворого. Розвиток печінкової дисфункції був більш характерним для тотального - у 18 $(94,7 \%)$ із 19 хворих і заднього ГГМ - у $3(37,5 \%)$ із 8 хворих. Серед причин летальності у 15 (88,2\%) із 17 померлих вказані ознаки печінкової дисфункції.

Ще одним серйозним ускладненням ГГм є порушення функції нирок, що супроводжується олігурією, зростанням концентрації креатиніну і сечовини в сироватці крові. Причиною цього може бути гіпоперфузія нирок внаслідок гіпотонії при септичному шоці чи прямого токсичного впливу на паренхіму нирок. Рівень креатиніну перевищував норму у 40 (61,5\%) хворих і становив у середньому $(171,2 \pm 9,5)$ мкмоль/л, рівень сечовини - у 42 (64,6\%) хворих і становив у середньому $(11,2$ $\pm 2,3)$ мкмоль/л. Протеїнурію виявлено у 54 (83,1\%) хворих, втрати білка становили від 0,033 до 0,135 г/л, у 16 (29,6\%) з них - білыше 0,099 г/л. За даними УзД нирок токсичні зміни паренхіми виявлені у 48 (73,8\%) із 65 хворих. Гостре ураження нирок діагностовано у 16 (24,6\%) із 65 хворих, із них у 7 застосовано гострий гемодіаліз, незважаючи на це, 5 (71,4\%) хворих померли. Серед причин летальності у 13 (76,5\%) із 17 померлих були порушення функції нирок.

Згідно з гайдлайнами 2016 - 2017 рр. на даний час розрізняють сепсис та септичний шок. Синдром поліорганної недостатності $(\mathrm{CПOH})$ як найважчий ступіть сепсису, сепсис та септичний шок діагностовані у 62 (95,3\%) хворих із ГГМ (табл.3).

Тяжкі форми сепсису, а саме септичний шок та СПОН, діагностовані у $13(68,4 \%)$ із 19 хворих з тотальним і у 3 (37,5\%) iз 8 - із заднім ГГМ. Із 11 хворих, у яких діагностовано СПОН, померли 10 (90,1\%), септичний шок - 5 (83,3\%), сепсис - 2 (4,3\%).

Таке ускладнення ГГМ, як гострі стресові ерозії та виразки травного каналу, виявляють у 75 - 80\% хворих.
Повідомляється про профузну кровотечу у просвіт травного каналу у $12 \%$ хворих із ГГМ [7]. Під час профілактичного проведення езофагогастродуоденоскопії у 19 хворих із ГГМ неускладнені гострі ерозії та виразки діагностовані у 10 (52,6\%), їм призначено противиразкове лікування. За наявності клінічних проявів шлунково-кишкової кровотечі гострі ерозії та виразки діагностовані у 27 (41,5\%) хворих. Під час проведення патологоанатомічного розтину у всіх 17 (100\%) померлих виявлено ерозивно-виразкові ураження стравоходу, шлунка чи дванадцятипалої кишки.

За нашими спостереженнями у хворих із заднім ГГМ часто виникає стійкий парез шлунково-кишкового тракту з можливим розвитком паралітичної кишкової непрохідності за рахунок втягнення у гнійно-запальний процес блукаючих нервів.

Внаслідок тяжкої гнійної інтоксикації у хворих із ГГМ виникають порушення психічного статусу, що супроводжуються в перші години захворювання вираженим збудженням 3 наступним гальмуванням, можливий розвиток деліріозних, аментивних та галюцинаторних станів [3]. За нашими даними, порушення свідомості (оглушення, сопор, енцефалопатія) були у 7 (10,7\%) хворих, які мали вкрай тяжкий стан.

Загрозливим ускладненням ГГМ є гостра профузна арозивна кровотеча з плевральної порожнини і середостіння. ІІї виникнення пов'язують з неадекватною санацією гнійного вогнища та розташуванням дренажів у безпосередньому контакті з стінкою великих судин середостіння. Можливе також виникнення арозивної кровотечі із судинного пучка шиї, плечеголовного стовбура, щитоподібних і міжреберних артерій [7]. У наших дослідженнях арозивна кровотеча діагностована у 2 (3,1\%) хворих, зокрема, при тотальному ГГМ - із верхньої порожнистої вени, передньо-верхньому - із загальної сонної артерії.

\section{Обговорення}

ГГМ залишається однією з актуальних проблем торакальної хірургії. Розвиток захворювання є швидким, агресивним і супроводжується системними порушеннями діяльності багатьох життево важливих органів і систем організму. Знання, своєчасна діагностика і лікування цих ускладнень - важлива органічна складова мультидисциплінарного лікування хворих та покращення його результатів.

\section{Висновки}

1. Виявлення ускладнень ГГМ та їх корекція є одним із вирішальних факторів в успішному лікуванні таких хворих. 
2. Найбільш загрозливі ускладнення виникали при поширених формах захворювання, зокрема, задньому і тотальному ГГМ.

3. Найчастіше ускладненнями ГГМ були ексудативний плеврит та емпієма плеври (76,9\%), гнійний бронхіт (80\%), пневмонія (70,7\%), ендо- і міокардит (59,2\%), гостре ураження нирок $(24,6 \%)$.

4. Із 11 хворих, у яких діагностовано СПОН, померли 10 (90,1\%), септичний шок - 5 (83,3\%), сепсис - 2 (4,4\%) хворих.

\section{References}

1. Abakumov MM, Pogodina AN, Barmina TG, Snigerov MV. Dvadcatiletniy opit diagnostiki I lecheniya pri razlichnih formah gnoynogo mediastenita. Vesnik hirurgiyi im. Grekova. 2001;(1): 80-5. [in Russian].

2. Slesarenko SS. Mediastinit. Moskwa: Medpraktika; 2005. 200 c. [in Russian].

3. Alsoub H, Chacko KC, Alsoub H. Descending necrotising mediastinitis. Postgrad Med J. 1995;71(832):98-101.

4. Shevchuk IM, Snizhko SS. Prichinu I puti rasprosraneniya flegmon shei, oslozhnonnuh nishodyachim gnoinum mediastinitom. Hirurgiya Vostocnaya Evropa. 2014;4(12):9-15. [in Russian].

5. Ohno K, Takada T, Terada M. Recovery from descending necrotizing mediastinitis and multiple organic failure after seven months of mechanical ventilation. Nippon Kyobu 4. Shikkan Gakkai Zasshi. 1996 Sep.;34(9):1021-9.

6. Moser JJ, Seiler C, Wagner HE. La place du traitement conservateur, $\mathrm{du}$ traitement chirurgical et de la radiologic interventionnelle dans les perforations et ruptures de l'oesophage. Helv Chir Acta. 1993 Sep;60(1-2):11-5.

7. Ventura Spagnolo E, Mondello C, Cardia L, Ventura Spagnolo O, Bartoloni G. Odontogenic abscess complicated by descending necrotizing mediastinitis: evidence of medical and dental malpractice. Minerva Stomatol. 2016 Dec;65(6):412-5. 